\title{
House Committee Cohesiveness as a Factor in Winning Conference Committee Outcomes
}

\author{
ROBERT E. DEWHIRST \\ Northwest Missouri State University
}

Frequently referred to as the "third house of Congress" by public officials and political scientists, conference committees have been the subject of numerous articles and books dating back to at least 1927, when an essentially descriptive study (McCown, 1927) outlined their origins and development. The impetus for the attention stems from the critical juncture conference committees occupy in the legislative process. Through sometimes lengthy and complex maneuvers, conference committee deliberations can and frequently do significantly alter legislation produced in one or both houses. Much of the attention of scholars and journalists has been directed toward attempting to determine why one house "wins" the conference deliberations (meaning which house came the closest to having its version of a bill reported out by the committee).

\section{The Research Question}

This study seeks to answer the question: Does the cohesiveness of House committees influence the outcome of conference committee legislation? Use of the term "cohesiveness" here is equivalent to Feig's definition of committee integration-the degree to which a committee's membership shares common norms and mores plus the extent to which members vote together on legislation (Feig, 1981). Use of the term "partisan" committees herein reflects the concept that members are likely to be divided along partisan lines.

Thus, the following hypothesis was formulated: Cohesive House committees will win more favorable conference committee reports than will partisan House committees. This hypothesis is based upon the premise that cohesive committees, when measured against the more divisive partisan committees, should enjoy a comparative tactical advantage when presenting legislation before conference committees. When compared with partisan committees, the relative strength of the cohesive committee's bargaining position should be manifested by a minimum level of dissension, both within the committee's presentation of the bill before the full House and through the level of opposition met during the roll call vote. Thus, House conference committee members taken from a cohesive committee should feel a minimum amount of pressure from their peers to make concessions favored by even a sizable minority of the members of the House.

Thus, this study will attempt to address a suggestion proposed in an earlier study (Vogler, 1970), which urged the investigation of the relations between standing committees and their parent bodies as a possibly significant factor influencing conference committee outcomes.

\section{Review of Previous Literature}

The fundamental question of determining which chamber won conference committee outcomes has been approached from many directions and with numerous empirical tools. The initial effort thirty years ago found that the House intended to have its way in conference committee deliberations (Steiner, 1951). 


\section{Robert E. Dewhirst}

While Steiner found that the House tended to prevail, the preponderance of evidence in the subsequent studies has supported the hypothesis that the Senate has tended to prevail, at least within the bounds of conference committee deliberations (Fenno, 1966; Manley, 1970).

Similarly, Kanter's work on defense budgets found that the Senate was predominantly successful in making changes to bills during conference sessions. However, the House was most successful, overall, in influencing the nature of defense appropriations. The frequent pattern of the House's policy-making process was: changing the President's appropriations requests, having them accepted by the Senate, and never discussing them during conference (Kanter, 1972).

Another scholar pointing toward the contextual dimensions of conference committee deliberations was Ferejohn in his examinations of rivers and harbors legislation. While his findings supported the earlier documentation of Senate dominance, Ferejohn postulated a unique interpretation of the data. He maintained that House members frequently will support deep budget cuts within their body, knowing that many of those cuts would be restored in conference action (Ferejohn, 1975).

Finally, Strom and Rundquist hypothesized that the Senate tends to win conference battles because it tends most frequently to act second to the House in initially passing the legislation. Thus, conference committee deliberations could best be understood as being processes in which members of the first acting body seek the support of those from the second acting chamber. The second acting body attains a strategic advantage in conference committee battles, because it has the ability to vote the compromises negotiated within the first acting body (Strom and Rundquist, 1977).

Yet, by examining the entire process which occurs before the legislation reaches conference, the authors concluded that the House has tended to exert greater influence on legislation than has the Senate. The House, because it more frequently adopts legislation first, is then able to set the basic parameters of legislation. The Senate, as the second body to examine bills, is then left basically to tinker with the proposal passed by the House. Conference deliberations, therefore, allow the House members to accept many of the Senate's amendments to their original bills (Strom and Rundquist, 1977).

\section{Methodology}

This project follows the example of the more recent studies and attempts to do more than merely identify conference committee "winners" and "losers". The goal herein is to shed some light upon the equally significant questions of how and why conference committees produce legislation as they do.

Success within conference committee deliberations was proposed here as being the dependent variable, to be based upon the independent variable of member cohesiveness of the House committee sponsoring the legislation. Based essentially upon Fenno (with supporting evidence from Vogler (1977)), Ways and Means was selected as an example of the more cohesive committees of the House and Education and Labor was selected to represent the less cohesive partisan committees.

House committee and subsequent conference committee reports of public bills involving each were examined over an 11-year period, from 1969 to 1979 . The procedure began by consulting the Congressional Information Service Abstracts for the period and identifying all legislation stemming from either House committee 


\section{House Committee Cohesiveness}

which eventually went to a conference session. Then, the original House legislation for each conference committee bill was identified.

The first of two major steps in the study sought to measure standing committee cohesiveness for each bill eventually reaching a conference committee. Information was gathered from House standing committee reports. When reported, the votes of the committee and subcommittee members were recorded. In addition, each subreport on every bill was analyzed. For each of these the number, viewpoint (normally, "favor," "oppose," "favor-- but with changes"), and number of signers (as well as signers of more than one report) were recorded.

Each bill in the analysis was classified as being either controversial or near unanimous within the sponsoring committee. If more than 20 percent of the committee voted against final passage in committee, a bill was classified as controversial. Near unanimous bills were those where more than 90 percent of the committee voted in favor of final passage. The 20 and 90 percent marks were selected because each appeared to represent a watershed separating the most intense viewpoints at each end of the spectrum of support for most bills.

The examination thus yielded two groups--unanimous/near unanimous and controversial--for each of the two House committees. The percentages of House recedes per bill (see Table 2 ) were then compared among each of the four resulting categories.

Moreover, an effort was made to incorporate into the study several of the bills which were adopted by their House standing committee without a voice vote. An attempt was made to classify several of these into one of the two categories used elsewhere in the study. Classification was estimated on the following basis: Bills were considered to be "controversial" if they had extensive sub-reports filed by opponents. Bills were class ified as "unanimous/near unanimous" when few (no opponents) or no sub-reports were filed with them.

Since this latter category was based upon contextual estimating, the generalizations and conclusions of this study are based largely upon the other phases of the data. However, the findings of this latter effort do not significantly alter the results of the study.

The second step of the study involved analyzing each conference committee report to attempt to establish to what extent the House conferees were successful in winning concessions from the Senate (see Table 1). The number of instances was counted when one chamber "receded" its version of the bill in favor of the rival document. Unfortunately, the explanations of the conference committee proceedings varied among the reports. Hence, sometimes other phrases led their issue to be classified as a "recede." For example, some reports might explain: "...the conference committee failed to adopt the Senate amendment," or "...the conference committee es sentially adopted the Senate version of this amendment to the bill." The analysis procedure basically avoided attempting to weight contextually-individual issues in which the chambers attempted to compromise, except where the "compromise" obviously favored one chamber's version.

\section{Findings}

The results of the study lead us to question the hypothesis that the more cohesive House committees (such as Ways and Means) are more likely to "win" 


\section{Robert E. Dewhirst}

conference committee deliberations than the less cohesive House committees (such as Education and Labor).

The findings suggest that the opposite of the hypothesis may be true. Clearly, the evidence supports the notion that, over an 11-year period, the House Education and Labor Committee fared better than the Ways and Means Committee in conference deliberations with senators (averaging 57.5 percent of the recedes per bill). This was clearly superior to the House Ways and Means Committee's performance during the same period, which averaged 78.8 percent of all recedes per bill. Moreover, the Education and Labor Committee averaged fewer recedes per bill than the Ways and Means Committee on every category compiled in the study.

In fact, the greatest difference between any of the two categories is found when comparing the maximum cohesive possibility against the maximum non-cohesive possibility (as illustrated on Table 2). The former category, Ways and Means on "unanimous/near unanimous" bills, had the highest percentage of recedes per bill79.0. Conversely, the latter category, Education and Labor on "controversial" bills, produced the lowest percentage of recedes per bill--56.3. Hence, this suggests that House standing committee cohesion, on legislation appearing before conference committees, may indeed be inversely correlated.

Table 1. "Winning" Chambers As Determined by Conference Reports*

\begin{tabular}{|c|c|c|c|}
\hline Ways and Means $(\mathrm{N}=37)$ & $\begin{array}{l}\text { House "wins" } \\
3(8.1 \%)\end{array}$ & $\begin{array}{l}\text { Senate "wins" } \\
32(86.4 \%)\end{array}$ & $\begin{array}{l}\text { Ties } \\
2(5.4 \%)\end{array}$ \\
\hline $\begin{array}{r}\text { Education and Labor }(\mathrm{N}=50) \\
\text { OVERALL }(\mathrm{N}=87)\end{array}$ & $\frac{12(24.0 \%)}{15(17.2 \%)}$ & $\frac{32(64.0 \%)}{64(73.6 \%)}$ & $\frac{6(12.0 \%)}{8(9.1 \%)}$ \\
\hline
\end{tabular}

*The "winner" was considered to be the chamber having the fewest recedes per bill. As in golf, the lower score here "wins". 


\section{House Committee Cohesiveness}

Table 2. "Comparing How The Two House Committees Fared in Conference Committees

Total House recedes
Average House

percent of total

Average House House and Senate

recedes per bill recedes per bill

\section{Ways and Means}

Unanimous/near-

unanimous bills $(\mathrm{N}=21) \quad 17$

Controversial bills $(\mathrm{N}=5) \quad 101$

8.4

79.0

\section{1}

$\underline{20.2}$

74.6

Totals $(\mathrm{N}=26)$

277

10.7

78.2

Controversial bills plus one deviant case $(\mathrm{N}=6)$

$\underline{496}$

82.7

$\underline{77.9}$

Totals with deviant case

$$
(\mathrm{N}=27)
$$

672

24.9

78.8

\section{Education and Labor}

Unanimous/near

unanimous bills $(\mathrm{N}=26) \quad 540$

20.8

58.0

Controversial bills $(\mathrm{N}=11) 280$

Totals $(\mathrm{N}=37)$

820

22.2

57.5

Note: All of the above cases were based upon House committee bills whose final passage was by a recorded tally.

Within a similar vein, the next observation, based upon the data, is that the "winning" percentages (see Table 1) here are slightly more unevenly distributed-73.6 percent for the Senate and 17.2 percent for the House--than the bulk of the findings of other efforts which tended to score Senate predominance between 60 and 70 percent of the time.

An interesting finding of the study was that there appeared to be more bargaining between the two chambers in conference committees when there was a controversial measure before the group. Both House committees recorded more recedes per "controversial" bill than "unanimous/near unanimous" ones. The 
Education and Labor Committee's rates of recedes per bill were 25.5 for "controversial" measures to 20.8 for the other, while those of the Ways and Means Committee were more unevenly distributed--20.2 to 8.4. These findings suggest, first, that measures deemed controversial within the Ways and Means Committee are much more likely to retain their controversial nature when discussed in conference committees. Conversely, when there is agreement within the Ways and Means Committee there is also a likelihood that there will be a similar consensus within the Senate Finance Committee. Second, there appears to be less of a potential for consensus between the Education and Labor Committee and its Senate counterpart. The House committee's rates of recedes per "non-controversial" measure were nearly as high as the average per "controversial" bill.

Another difference in bargaining levels can be seen between the activities of the two House committees themselves. Education and Labor conference committee members were much more active (and successful) in "give- and-take" with their Senate counterparts than were members of the Ways and Means Committee. Education and Labor averaged 22.2 recedes (and a smaller share of the total) to the 10.7 of Ways and Means. The difference in aggregate recedes between the two House committees was even greater--820 for Education and Labor to 277 for Ways and Means. 


\section{Implications}

Assessment observations begin by agreeing with an earlier assertion that there is no single variable which fully explains conference committee outcomes. This rejection of a single cause also, in a sense, carries over to assessing Fenno's (1966) proposition that research in this area should begin by attempting to determine which chamber "won" or "lost" conference outcomes. Yet, this study and several previous efforts have measured Fenno's concept from various approaches, with not entirely satisfactory results.

The suggestion here is that scholars too frequently have failed to distinguish between the question of determining which chamber "won" or "lost" in conference with a much larger issue of learning which house is, and under what circumstances, more influential than the other. As subsequent scholars, especially Strom and Rundquist, have noted, conference committee deliberations should be examined within the greater political context of overall congressional politics. As Strom and Rundquist argue, strategic advantages, acquired either by chance or purpose before the issue goes to conference committee, may determine the overall impact of the bill -- perhaps regardless of what happens in conference committee negotiations.

Much of this latter problem is possibly related to a significant obstacle confronting research in this area. That problem is one of the scholar's being able to assess correctly the weights to be assigned to various elements inserted into a bill, either during conference committee bargaining sessions or within one of the chambers. For example, a house might prevail on "only" one issue on a bill. Yet, that issue might be of equal political or policy weight to all of the concessions that that chamber had to make to win it. Thus, scholarly contextual analysis might fail to detect this, an item perhaps only participants would be aware of. Policy choices (such as appropriations levels) would appear to be the easiest to measure. Political weighting (including the possibility of trading concessions on one bill for others on a subsequent measure) could be a much more slippery variable to grasp.

A suggestion here is for scholars to consider setting aside the narrower concern of "who wins in conference" and addressing a more pertinent, far-reaching question-which chamber is more influential, and why? To be sure, conference committee deliberations would be one of the logical areas in which research would be conducted. But, as Strom and Rundquist and others have suggested, the dynamics of the political process here are much broader than that.

For example, another avenue might be to examine personal dimensions in conference committee settings. Questions which might be addressed are: How influential are chamber standing committee chairmen or house conference delegation leaders (usually the same people)? To what extent are conference committee deliberations influenced by member goals, or personal rivalries (perhaps between the heads of House vs. Senate delegations, as developed over time)?

An attempt has been made through this study to tie conference committee proceedings to a political dimension-cohesiveness of standing committees-within one chamber, the House, over time. The results of the examination, which failed to substantiate the hypothesis--indeed, they suggest the opposite--do not inhibit notions of multi-casual factors influencing conference committee outcomes. Indeed, this orientation suggests that the basic question should be expanded to a broader concern of attempting to determine which chamber has more influence, and under what circumstances. 


\section{Robert E. Dewhirst}

In conclusion, one feels compelled to speculate on why the findings of the study uncovered results the opposite of the hypothesis. First, perhaps the number of recedes fails to accurately reflect the proper power balance between the House and Senate delegations to conference committees. As outlined earlier herein, the weight of the fewer Senate recedes to Ways and Means Committee delegations might exceed the overall degree of concessions made from the aggregate of the House members' recedes. Unfortunately, there would be significant obstacles to accurately weighing each recede recorded in conference. First, it would be rather difficult to weight recedes later by analyzing the text of conference legislation. It would be difficult to know the contemporary political weight of each recede recorded. Second, it would be difficult to extract an unbiased appraisal from any of the conference committee members. Members of each delegation would be unlikely to admit that their delegation had been outmaneuvered politically.

A related notion might be one suggested by Fenno. When discussing the conference committee behavior of the House Appropriations Committee, Fenno argued that the representatives tended to establish the basic appropriations policies which were subsequently tinkered with by their counterparts in the Senate. Thus, the Senate committee served as a "court of appeals" for anguishing interest groups. This would enable House delegations to yield more recedes in conference, but only at the considerable cost of senators having the House set the basic dimensions of the appropriations measures. Perhaps this could have happened in tax legislation as well; the senators were making minor changes to legislation essentially developed by the House Ways and Means Committee.

Third, there is the possibility that there was more substantive agreement between the two rival committees on education and labor policies than between the Ways and Means Committee and its counterpart in the Senate. However, this does not appear to be likely, considering the ideological and partisan dimensions of the frequently volatile issues addressed by those committees.

Finally, perhaps the Senate committees possessed as much (or more) group cohesion as their counterparts in the House. Thus, the strength of the House conference committee delegations could be matched (or even outmatched) by the groups from the Senate. However, the goal of this study was to examine the effects, if any, of committee cohesion within only the House. It would appear to be a next logical step for future researchers to examine the influence of cohesion among Senate committees on Senate conference committee delegations.

\section{References}

Feig, Douglas G. (1981). "Partisanship and Integration in Two House Committees: Ways and Means and Education and Labor, "Western Political Quarterly, Vol. 34, pp. 426-437.

Fenno, Richard F. (1966). The Power of the Purse: Appropriations Politics in Congress. Boston: Little, Brown.

Fenno, Richard F. (1973). Congressmen in Committees. Boston: Little, Brown.

Ferejohn, John A. (1974). Pork Barrel Politics: Rivers and Harbors Legislation, 1947-1968. Stanford: Stanford University.

Ferejohn, John A. (1975). "Who Wins in Conference Committee?' The Journal of Politics, Vol. 37, pp. 1033-1046.

Kanter, Amold. (1972). "Congress and the Defense Budget: 1960-1970," American Political Science Review, Vol. 66, pp. 129-143. 


\section{House Committee Cohesiveness}

Manley, John F. (1970). The Politics of Finance: The House Committee on Ways and Means. Boston: Little, Brown.

McCown, Ada C. (1927). The Congressional Conference Committee. New York: Columbia University.

Steiner, Gilbert Y. (1951). The Congressional Conference Committee: Seventieth to Eightieth Congresses. Urbana: University of Illinois.

Strom, Gerald S. and Rundquist, Barry S. (1977). "A Revised Theory of Winning in House-Senate Conferences," The American Political Science Review, Vol. 71, pp. 448-453.

U.S. Congress, House of Representatives, Reports on Public Bills, from second session, 91 st Congress, through first session, 96 th Congress.

Vogler, David J. (1970). "Patterns of One House Dominance in Congressional Conference Committees," Midwestern Journal of Political Science, Vol. 14, pp. 303-320.

Vogler, David J. (1971). The Third House: Conference Committees in the United States Congress. Evanston: Northwestern University. 